\title{
Contribution to the knowledge of limoniid flies (Diptera: Limoniidae) from the Dominican Republic, with the description of a new species of Geranomyia Haliday, 1833 and 12 newly recorded species
}

\author{
K познанию комаров-цимониид (Diptera: Limoniidae) из \\ Аоминиканской Респубцики, с описанием нового вида рода \\ Geranomyia Haliday, 1833 и 12 видами, впервые отмеченными \\ Аля фауны страны
}

\author{
D.I. Gavryushin \\ А.И. Гаврюшин
}

\begin{abstract}
Zoological Museum, Moscow Lomonosov State University, Bol'shaya Nikitskaya 2, Moscow 125009, Russia. E-mail: dmitry_gavryushin@yahoo.com

Зоологический музей, Московский государственный университет им. М.В. Ломоносова, Большая Никитская ул., 2, Москва 125009, Россия.
\end{abstract}

KEYWORDS: Diptera, Limoniidae, Chioneinae, Limnophilinae, Limoniinae, Geranomyia, Dominican Republic, Greater Antilles, Neotropical region, taxonomy, description, new species, new records.

КЛЮЧЕВЫЕ СЛОВА: Diptera, Limoniidae, Limnophilinae, Chioneinae, Limnophilinae, Limoniinae, Geranотуіа, Доминиканская Республика, Большие Антильские острова, Неотропическая область, таксономия, описание, новый вид, новые находки.

ABSTRACT. A new species of limoniid fly (Diptera: Limoniidae) is described from the Dominican Republic, Geranomyia constanza, sp.n. Twelve species of limoniid flies (Diptera: Limoniidae) are recorded as new to the fauna of the Dominican Republic.

How to cite this article: Gavryushin D.I. 2018. Contribution to the knowledge of limoniid flies (Diptera: Limoniidae) from the Dominican Republic, with the description of a new species of Geranomyia Haliday, 1833 and 12 newly recorded species // Russian Entomol. J. Vol.27. No.1. P.61-66. doi: 10.15298/rusentj.27.1.10

РЕЗЮМЕ. Новый вид комара-лимонииды (Diptera: Limoniidae) описан из Доминиканской Республики: Geranomyia constanza, sp.n. Двенадцать видов комаров-лимониид (Diptera: Limoniidae) впервые указываются для фауны Доминиканской Республики.

\section{Introduction}

Twenty-six species of limoniid flies have been previously recorded from the island of Haiti, the secondlargest one among the islands of the Greater Antilles, including $9 \mathrm{spp}$. from Haiti and $17 \mathrm{spp}$. from the Dominican Republic [Oosterbroek, 2017]. This number is small even when compared with the number of species known from other islands of the Greater Antilles, 66 spp. recorded from Jamaica, $61 \mathrm{spp}$. known from Cuba, and $54 \mathrm{spp}$. discovered in Puerto Rico. A notable exam- ple of species richness of a regional island fauna is the island of Dominica (the Windward Islands of the Lesser Antilles Archipelago), where limoniid flies were extensively collected, mostly by the members of the staff of the United States National Museum during the BredinArchbold Biological Survey of Dominica; the resulting study contained descriptions of 24 new species and 1 new subspecies [Alexander, 1970]. Currently, 74 spp. of limoniid flies are known from this relatively small island (750 sq. km). More interesting finds and undescribed taxa can be anticipated once some new regional material is available; so a rather small batch of limoniid flies (96 specimens) collected by Nikita Vikhrev in late February and early March of 2016 in the Dominican Republic included a species of Geranomya new to science and 12 species representing new records for the fauna of Dominican Republic.

\section{Material and methods}

The morphological terms used here mainly follow McAlpine [1981], venation is described mostly after Alexander and Byers [1981]. Male genitalia were boiled in 10\% solution of potassium hydroxide $(\mathrm{KOH})$ for 60 to $90 \mathrm{~s}$, neutralised by a $10 \%$ solution of acetic acid $\left(\mathrm{CH}_{3} \mathrm{COOH}\right)$, rinsed in water and then stored in glycerol. Dissected male genitalia were examined with a Nikon SMZ645 binocular microscope and then photographed using an eTREK DCM900 camera on MBI-1 microscope; images were processed with either CombineZP (Alan Hadley, http:// 
www.hadleyweb.pwp.blueyonder.co.uk) or Zerene Stacker (http://www.zerenesystems.com) software. The wing of Shannonomyia batesi was photographed with a Nikon D70s DSLR camera. Type material is deposited in the Zoological Museum of the Moscow State University (ZMMU).

All examined material was collected by Nikita Vikhrev and consists of dried specimens glued to insect pins. The collecting localities are as follows:

Macao - DOMINICAN REPUBLIC, La Altagracia Province, Punta Cana, Playa de Macao, $18.76^{\circ} \mathrm{N}, 68.53^{\circ} \mathrm{W}$

Jarabacoa - DOMINICAN REPUBLIC, La Vega Province, Jarabacoa env., $19.088^{\circ} \mathrm{N}, 70.676^{\circ} \mathrm{W}, 580 \mathrm{~m}$ a.s.1.

Constanza - DOMINICAN REPUBLIC, La Vega Province, Constanza env., $18.916^{\circ} \mathrm{N}, 70.723^{\circ} \mathrm{W}, 1250 \mathrm{~m}$ a.s.1.

Río San Juan - DOMINICAN REPUBLIC, María Trinidad Sánchez Province, Río San Juan env., $19.63^{\circ} \mathrm{N}, 70.078^{\circ} \mathrm{W}$

San José de Ocoa - DOMINICAN REPUBLIC, San José de Ocoa Province, San José de Ocoa env., $18.53^{\circ} \mathrm{N}$, $70.504^{\circ} \mathrm{W}, 400 \mathrm{~m}$ a.s.1.

Socoa R. - DOMINICAN REPUBLIC, Monte Plata Province, Socoa River, Salto de Socoa Waterfall env., $18.88^{\circ} \mathrm{N}, 69.72^{\circ} \mathrm{W}, 150 \mathrm{~m}$ a.s. 1 .

\section{Taxonomic part}

\section{Species description \\ Geranomyia constanza Gavryushin, sp.n. Figs 1-6.}

MATERIAL EXAMINED. Holotype, $\sigma^{7}$, Constanza, 27 28.II.2016; paratype,, , same data.

DIAGNOSIS. Size small (wing of male less than $6 \mathrm{~mm}$.), general colouration yellow, restrictedly tinged with green, prescutum unmarked; legs yellow; wings subhyaline, unmarked except for the distinct stigma; $S c$ ending at midlength of $R s$; male hypopygium with rostral prolongation of the ventral lobe of gonostylus short and stout, the two spines placed close together on a common low tubercle near midlength of the prolongation; dorsal lobe of gonostylus with tip obtuse.

DESCRIPTION. Male. Measurements. Wing length, 5.7 $\mathrm{mm}$. Head brown above, with greyish pruinosity and black hairs, greenish yellow below. Eyes closely approximated, anterior vertex narrower than one-half the diameter of the scape. Rostrum yellow at base, brown yellow distally, palpi short, brown, 2-segmented (rostrum broken slightly beyond the palpi). Antennae with scape yellow, pedicel brown yellow, flagellum lacking.

Thorax: general colouration yellow, pleurae ventrally paler yellow. Halteres with base of stem yellow, median portion of stem greenish yellow, knob dark brown. Legs with coxae yellow, trochanters greenish, the remainder broken. Abdomen yellow, basal segments tinged with green.

Wings subhyaline, iridescent, weakly yellowish; stigma distinct, oval, yellowish grey; veins brown, paler at base of wing. Macrotrichia on $R, R, R s$, and longitudinal veins beyond cord from $R_{3}$ to $C u A_{2}$, inclusive, additionally on veins $M$ and $C u A$ beyond the level of origin of $R s$. Venation (Fig. 1): $S c_{1}$ ending at midlength of $R s, S c_{2}$ shortly removed, at roughly two-fifths the length of $R s$; a supernumerary crossvein in cell $s c$ at mid-distance between the humeral crossvein and the origin of $R s ; R s$ oblique, almost straight, approx. 2.5 times longer than the basal section of $R_{4+5}$ one-half longer than $R_{2+3}$, subequal to $R_{3} ; R_{1+2}$ one-half shorter than strongly curved $R_{2} ; R_{2+3}$ about one-half longer than the basal section of $R_{4+5}$; cell $r_{3}$ one-third wider than $r_{5}$; crossvein $r$ - $m$ very short, transverse; cell $d m$ longer than both the distal section of $\mathrm{CuA}$ and $M_{3}$, subequal to $M_{1+2}$; crossvein $m-m$ one-half shorter than basal section of $M_{3}$; basal section of $C u A_{1}$ oblique, less than one-fifth its length beyond the fork of $\mathrm{M}$, subequal to $C u A_{2}$. Vein $C u P$ reaches the fork of $C u A$. Vein $A_{1}$ ending opposite the level of $S C_{2}$; vein $A_{2}$ ending shortly before the level of the supernumerary crossvein in cell $s c$.

Abdomen yellow, the basal segments tinged with green. Hypopygium (Figs 2-6) with the tergite 9 transverse, twice wider than long, its posterior border with a moderately deep median notch, the broadly obtuse lateral lobes thus formed with abundant long setae; gonocoxite relatively short, the ventromesal lobe small, with a smaller accessory setiferous lobule on outer face near base; dorsal lobe of gonostylus a weakly pigmented rod, subequal in length to the gonocoxite, curved on outer half, the tip obtuse; ventral lobe of gonostylus large, fleshy, almost three times the length of gonocoxite, rostral prolongation short and stout, its tip obtuse, the two reddish yellow, slightly unequal spines placed close together on a low common tubercle near midlength of the rostral prolongation, the shorter spine subequal in length to the prolongation beyond; aedeagus (Figs 4-5) relatively short and stout, at apex with two conspicuous subtriangular lobes; paramere with mesal-apical lobe slender, gently curved to the short acute point, the concave margin with a low flange which apparently is microscopically serrulate.

Female. Measurements. Wing length, $5.9 \mathrm{~mm}$, rostrum, $2.3 \mathrm{~mm}$. Generally similar to male yet certain details should be noted. Antennae with scape greenish brown, flagellomeres oval, more elongate-oval distally, sparsely yellowish pubescent, verticils shorter than corresponding segments, terminal flagellomere shorter than the penultimate. Prescutum with lateral margins behind the pseudosutural foveae widely brownish. Scutal lobes with outer margins brownish, median areas of scutum and scutellum greenish. Legs long, fore legs about two and a half times the length of body; coxae and trochanters greenish, the remainder mostly yellow, femoral apices weakly dilated and darkened, the tips greenish; tarsi with tips darkened (right mid leg and both hind legs lacking). Abdominal tergites greenish yellow, the lateral margins narrowly and indistinctly darkened, sternites paler yellow with greenish tints. Wings with $R s$ only slightly longer than $R_{2+3}$, shorter than $R_{3}$, about twice as long as the basal section of $R_{4+5}^{2+3}$; cell $d m$ longer than the distal section of $\mathrm{Cu} A_{1}$, subequal to $M_{3} ; m$-cu very shortly before the fork of $M$. Ovipositor with cerci long, slender, nearly straight, sternite 8 and hypovalvae extensively green, the latter terminating at about three-fourths the length of cerci.

DISTRIBUTION. Dominican Republic.

ETYMOLOGY. The species is named after Constanza, a town in La Vega Province, in the vicinity of which it was collected.

DISCUSSION. Among the regional species with wings unpatterned and rostrum moderately long, Geranomyia constanza, sp.n., is most similar to G. subvirescens subvirescens (Alexander, 1930) [Alexander, 1930: 112] described from Cuba, also recorded from Dominica, Panama, and Venezuela, the male hypopygium illustrated in Alexander, 1970 [Alexander, 1970: 19, fig. 22], differing mostly in the structure of the male hypopygium, notably the obtuse tip of the dorsal lobe of gonostylus and an accessory lobule on the ventromesal lobe of gonocoxite. The two structural features of the male hypopygium mentioned above are known in a small number of the Neotropical species yet a combination of both of these characters has not been yet recorded in any of described regional species. 
New records

Subfamily Chioneinae

Erioptera (Mesocyphona) caliptera caliptera

Say, 1823

Fig. 7.
Can be told from the numerous regional representatives of the subgenus by the wing pattern, colouration of legs and details of the male hypopygium (Fig. 7).

DISTRIBUTION. Widely distributed in the Nearctic and Neotropical regions (Canada, USA, Cuba, Bolivia, Dominica, St Vincent, Puerto Rico), Dominican Republic (first record).
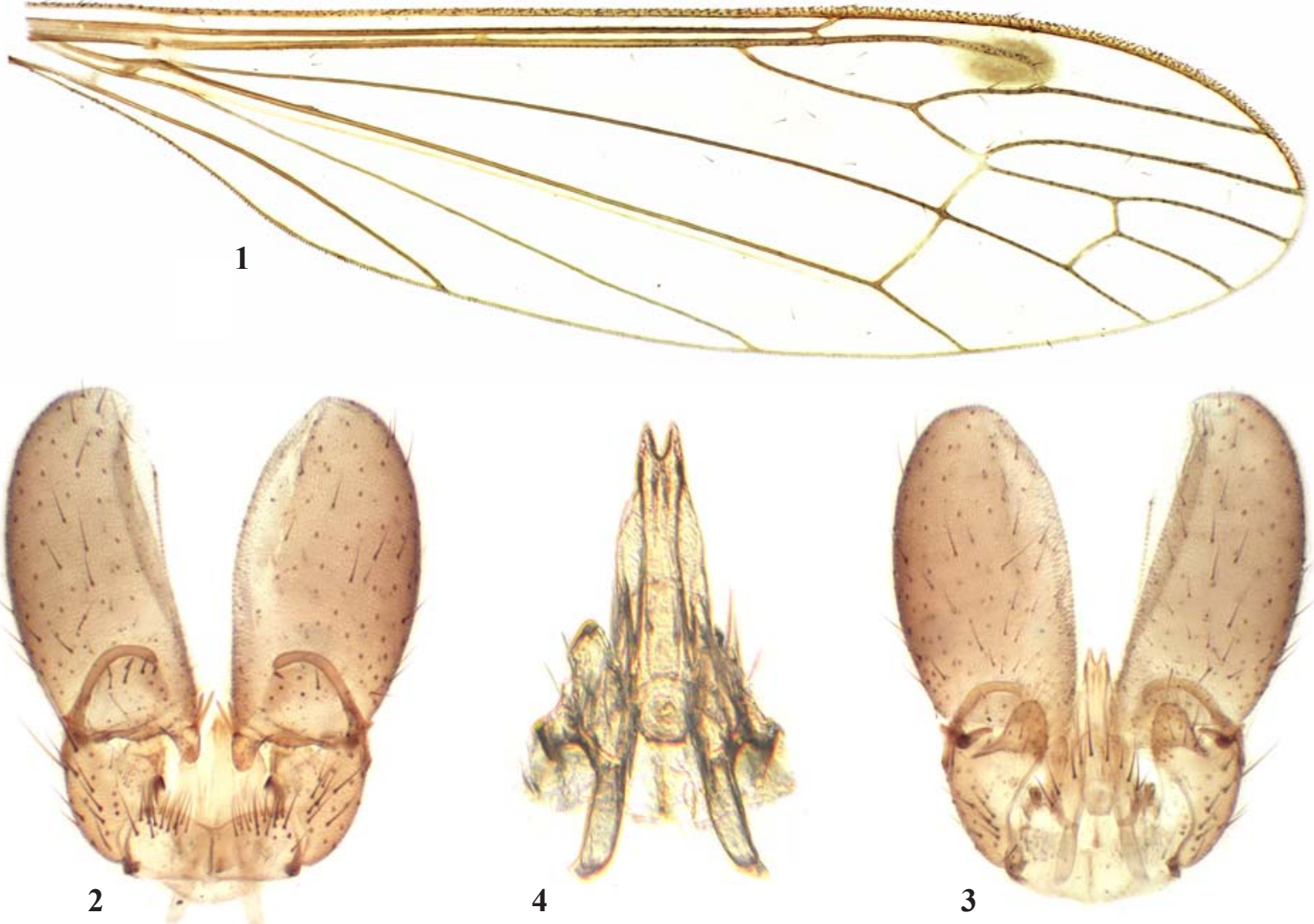

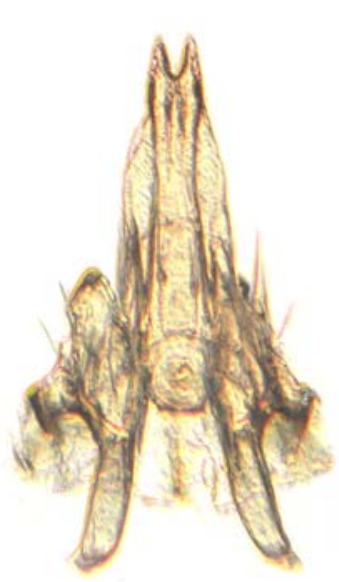

4

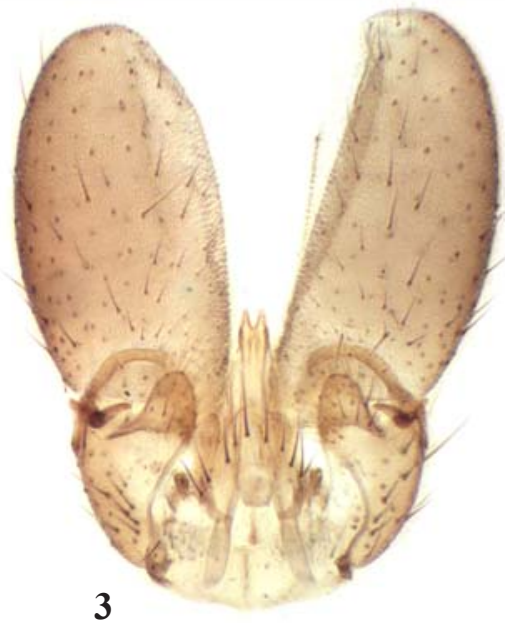

3

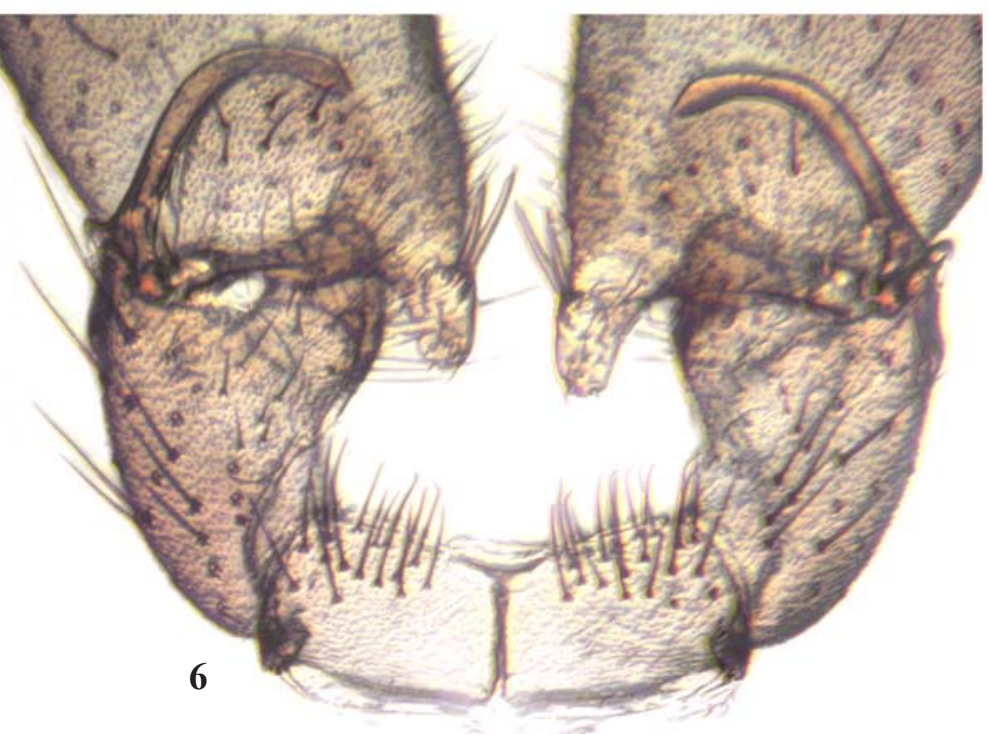

Figs 1-6. Geranomyia constanza sp.n., holotype $0^{7}$ : 1 - right wing; 2-3 - hypopygium; 4-5 - aedeagal complex; 6 - hypopygium, aedeagal complex removed (detail at higher magnification); $1-2,4,6$ - dorsal view; 3 - ventral view; 5 - lateral view. Not to the same scale.

Рис. 1-6. Geranomyia constanza sp.n., голотип О’: 1 - правое крыло; 2-3 - гипопигий; 4-5 - эдеагус; 6 - гипопигий, эдеагус удалён (детали строения при большем увеличении); 1-2, 4, 6- сверху ; 3 - снизу; 5 - сбоку. Масштаб разный. 

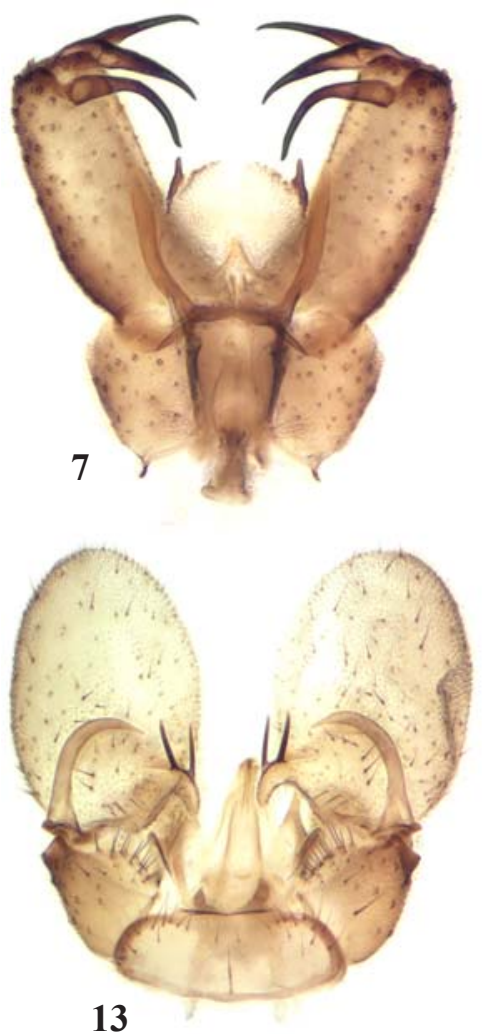

13
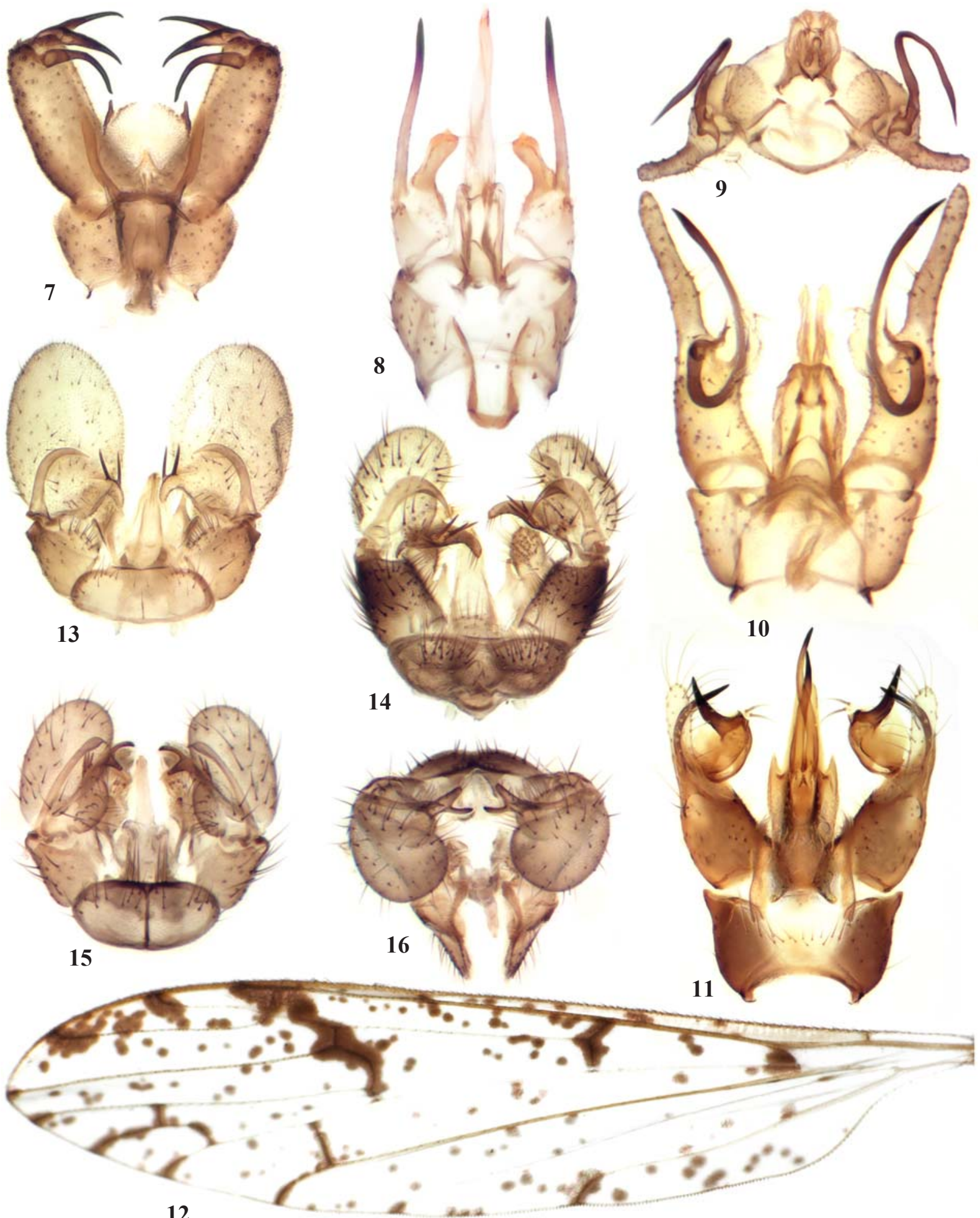

Figs 7-16. Limoniidae spp.: 7 - Erioptera (Mesocyphona) caliptera caliptera, O'; 8 - Gonomyia (Leiponeura) orthomera, O; 9-10 Gonomyia (Leiponeura) producta, ơ; 11 - Gonomyia (Paralipophleps) peracuta peracuta, o7; 12 - Shannonomyia (Shannonomyia) batesi, ; 13 - Dicranomyia (Dicranomyia) brevivena torrida, O'; 14 - Dicranomyia (Dicranomyia) distans, o': 15-16 — Dicranomyia (Dicranomyia) divisa, $\bigcirc^{7}$; 7-11, 13-16 - hypopygium; 12 - left wing; 7-8, 10-15 - dorsal view; 9, 16 - caudal view. Not to the same scale.

Pис. 7-16. Limoniidae spp.: 7 - Erioptera (Mesocyphona) caliptera caliptera, $\bigcirc^{7} ; 8$ - Gonomyia (Leiponeura) orthomera, O'; 9-10 Gonomyia (Leiponeura) producta, O; 11 - Gonomyia (Paralipophleps) peracuta peracuta, ơ; 12 - Shannonomyia (Shannonomyia) batesi, +13 - Dicranomyia (Dicranomyia) brevivena torrida, ơ; 14 - Dicranomyia (Dicranomyia) distans, ơ'; 15-16 - Dicranomyia (Dicranomyia) divisa, o'; 7-11, 13-16 - гипопигий; 12 - левое крыло; 7-8, 10-15 - сверху; 9, 16 - сзади. Масштаб разный. 


\section{Erioptera (Mesocyphona) immaculata immaculata} Alexander, 1913.

MATERIAL EXAMINED. 1 \%, Río San Juan, 02.III.2016. Distinguished from the regional species of the subgenus with unspotted wings by femora with a narrow brown subapical ring and other details of colouration.

DISTRIBUTION. USA (Texas), Guatemala, Guyana, Mexico, Nicaragua (type locality), Dominican Republic (first record).

Gonomyia (Leiponeura) orthomera Alexander, 1937

\section{Fig. 8.}

MATERIAL EXAMINED. $90^{7} \sigma^{7}, 6$, 9 , Jarabacoa, 01.III.2016.

Differs from the regional members of the manca group in the structure of the male hypopygium (Fig. 8). record)

DISTRIBUTION. Puerto Rico, Dominican Republic (first

Gonomyia (Leiponeura) producta Alexander, 1919 Figs 9-10.

MATERIAL EXAMINED. $1 \sigma^{7}$, Jarabacoa, 01.III.2016.

Another member of the manca group, readily told from other regional species by the structure of the male hypopygium, especially gonocoxites and outer gonostyli (Figs 9-10).

DISTRIBUTION. Antigua (type locality), Dominica, Ecuador, Mexico, Puerto Rico, Dominican Republic (first record).

Gonomyia (Paralipophleps) peracuta peracuta Alexander, 1928

Fig. 11.

MATERIAL EXAMINED. $10^{7}$, Constanza, 27-28.II.2016.

Differs from the regional species of Gonomyia (Paralipophleps) Alexander, 1947 in the structure of the male hypopygium (Fig. 11).

DISTRIBUTION. Mexico (type locality), Jamaica, Dominican Republic (first record)).

\section{Subfamily Limnophilinae}

Shannonomyia (Shannonomyia) batesi

Alexander, 1939

Fig. 12.

MATERIAL EXAMINED. 1 ㅇ, Constanza, 27-28.II.2016.
Readily told from the regional members of the mesophragma group (a supernumerary crossvein in cell $r$ ) by the numerous dots in the cells of the wings (Fig. 12) and the heavy dark pattern of the femora.

DISTRIBUTION. Haiti, Dominican Republic (first record))

\section{Subfamily Limoniinae}

Dicranomyia (Dicranomyia) brevivena torrida

(Alexander, 1933)

Fig. 13.

MATERIAL EXAMINED. $90^{\top} \sigma^{\top}, 6$ 우, Macao, 21-22.II.2016; $3 \bigcirc^{7} \sigma^{7}$, Constanza, 27-28.II.2016.

Differs from the nominative subspecies (widespread in Canada and USA, also Bermuda) and Dicranomyia (Dicranomyia) brevivena capra (Alexander, 1947) (Venezuela, Bolivia) mostly in the details of colouration.

DISTRIBUTION. Puerto Rico (type locality), Jamaica, Dominican Republic (first record).

\section{Dicranomyia (Dicranomyia) distans \\ Osten Sacken, 1860}

Fig. 14.

MATERIAL EXAMINED. $1 \sigma^{7}, 4$, + , Constanza, 27-28.II.2016; $10^{\top}, 3$ 우, Río San Juan, 02.III.2016.

Distinguished from the regional species with the closed cell $d m$ by a combination of the details of colouration, venation and structure of the male hypopygium (Fig. 14).

DISTRIBUTION. Widely distributed in North, Central, and South America, from USA south to California, Alabama, Texas, and Florida (type locality) to Paraguay and Brazil, also Gough Island and Tristan da Cunha Archipelago (probably introduced), Dominican Republic (first record).

\section{Dicranomyia (Dicranomyia) divisa}

(Alexander, 1929)

Figs 15-16.

MATERIAL EXAMINED. $10^{7}, 1$, Constanza, 27-28.II.2016.

Readily told from the regional members of the genus with the closed cell $d m$ by the structure of the male hypopygium, especially the bifid apex of the rostral prolongation (Figs 15-16).

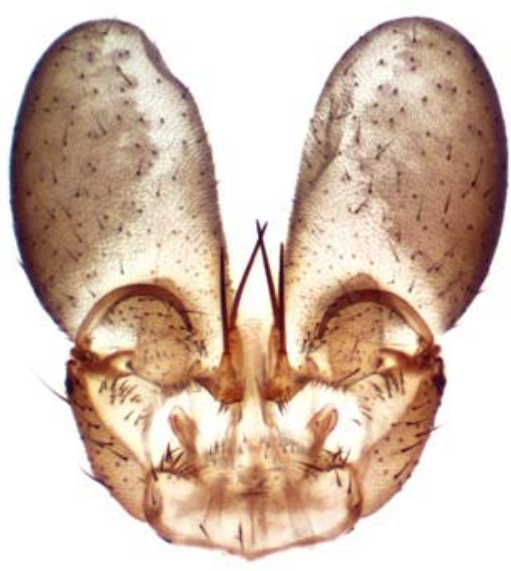

17
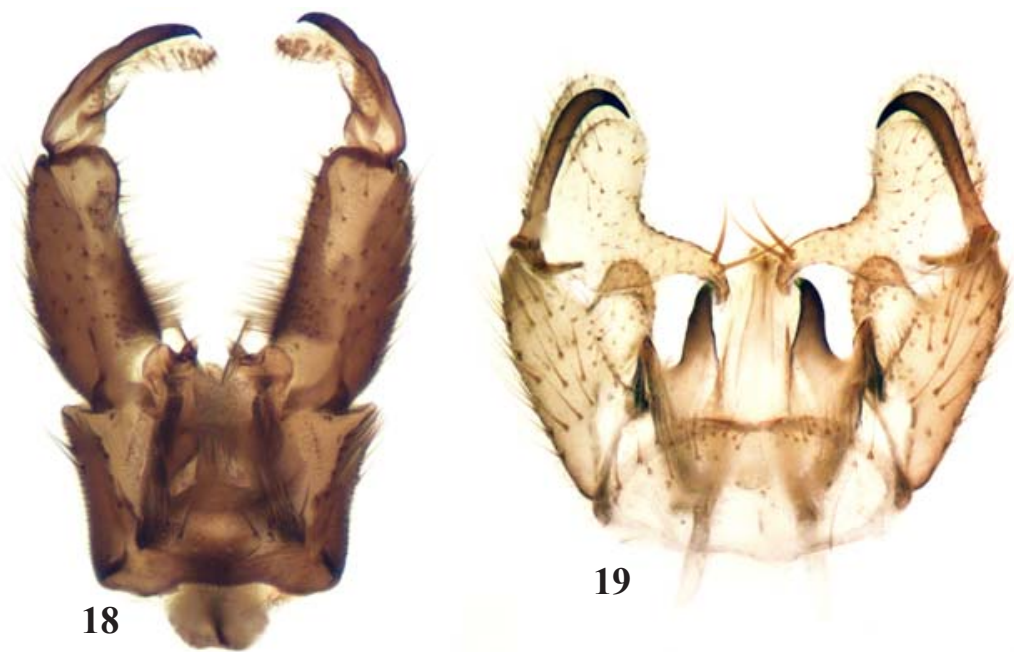

Figs 17-19. Limoniidae spp., O', hypopygium, dorsal view: 17 - Geranomyia banksiana; 18 - Orimarga (Orimarga) perpallens; 19 Rhipidia (Rhipidia) pratti. Not to the same scale.

Рис. 17-19. Limoniidae spp., О', гипопигий, сверху: 17 - Geranomyia banksiana; 18 - Orimarga (Orimarga) perpallens; 19 Rhipidia (Rhipidia) pratti. Масштаб разный. 
DISTRIBUTION. USA (type locality), Dominica, Haiti, Jamaica, Puerto Rico, Dominican Republic (first record).

Geranomyia banksiana (Alexander, 1939)

Fig. 17.

MATERIAL EXAMINED. $2 \sigma^{\top} \sigma^{\top}, 2$ 우, San José de Ocoa, 26.II.2016.

Amply different from the related regional species with unpatterned wings and moderately long rostrum in the structure of the male hypopygium (Fig. 17).

DISTRIBUTION. Cuba, Dominican Republic (first record).

Orimarga (Orimarga) perpallens Alexander, 1964

Fig. 18.

MATERIAL EXAMINED. 1 ○', Socoa R., 03.III.2016.

Differs from the regional members of the nominative subgenus in the structure of the male hypopygium (Fig. 18) and venation, especially large cell $a 2$.

DISTRIBUTION. Jamaica, Dominican Republic (first record).

Rhipidia (Rhipidia) pratti (Alexander, 1950)

Fig. 19.

MATERIAL EXAMINED. $1 \sigma^{7}, 1$, , Constanza, 27-28.II.2016; 1 q, Jarabacoa, 01.III.2016.

Can be told from the regional species with weakly produced to subpectinate antennal flagellomeres in males by the structure of the male hypopygium (Fig. 19).

DISTRIBUTION. Puerto Rico, Dominican Republic (first record).

Other species examined

\section{Subfamily Chioneinae \\ Gonomyia (Gonomyia) sp.}

MATERIAL EXAMINED. 1 , Constanza, 27-28.II.2016.

In venational details, this fly is similar to some regional members of the subgenus, including Gonomyia (Gonomyia) brevicula Alexander, 1926 (Cuba), Gonomyia (Gonomyia) jamaicana Alexander, 1964 (Jamaica), and Gonomyia (Gonomyia) subbrevicula Alexander, 1947 (Puerto Rico). The absence of the male sex doesn't allow to provide a species name.

Gonomyia (Paralipophleps) pleuralis (Williston, 1896).

MATERIAL EXAMINED. $3 \sigma^{7} \sigma^{7}, 2$ 우, Río San Juan, 02.III.2016.
Subfamily Limoniinae

Geranomyia tibialis (Loew, 1851).

MATERIAL EXAMINED. 2 O $^{7}$, Jarabacoa, 01.III.2016.

\section{Geranomyia $\mathrm{sp}$.}

MATERIAL EXAMINED. 1 , , Socoa R., 03.III.2016.

A single damaged female specimen (legs lacking) can not be properly named.

Rhipidia (Rhipidia) domestica Osten Sacken, 1860.

MATERIAL EXAMINED. $4 \sigma^{7} \sigma^{7}, 4$ 우, Constanza, 2728.II.2016.

Rhipidia (Rhipidia) schwarzi Alexander, 1912.

MATERIAL EXAMINED. 1 o", Río San Juan, 02.III.2016.

Toxorhina (Toxorhina) domingensis

Alexander, 1937.

MATERIAL EXAMINED. 1 ○’, Río San Juan, 02.III.2016.

ACKNOWLEDGEMENTS. I would like to express my sincere gratitude to Dr. Nikita E. Vikhrev (Zoological Museum of Moscow University, Moscow, Russia) for providing interesting material of exotic short-palped crane-flies and for continuing support and encouragement.

\section{References}

Alexander C.P. 1930. Records and descriptions of Neotropical crane-flies (Diptera: Tipulidae), VIII // Journal of the New York Entomological Society Vol.38. No.2. P.109-120.

Alexander C.P. 1970. Bredin-Archbold-Smithsonian biological survey of Dominica. The crane flies (Diptera: Tipulidae) // Smithsonian Contributions to Zoolology Vol.45. P.1-59.

Alexander C.P., Byers G.W. 1981. Tipulidae // McAlpine J.F., Peterson B.V., Shewell G.E, Teskey H.J., Vockeroth J.R., Wood D.M. (coordinators). Manual of Nearctic Diptera. Vol.1. Research Branch. Agriculture Canada. Monograph 27. Ottawa. P.153-190.

McAlpine J.F. 1981. Morphology and terminology-adults // McAlpine J.F., Peterson B.V., Shewell G.E, Teskey H.J., Vockeroth J.R., Wood D.M. (coordinators). Manual of Nearctic Diptera. Vol.1. Research Branch. Agriculture Canada. Monograph 27. Ottawa. P.9-63.

Oosterbroek P. 2017. Catalogue of the Craneflies of the World ((Diptera, Tipuloidea: Pediciidae, Limoniidae, Cylindrotomidae, Tipulidae), online at: http://ccw.naturalis.nl/ (last accessed November 08, 2017). 